Journal of Economic and Social Measurement 15 (1989) 302

\title{
CONTENTS OF VOLUME 15
}

W. HAMLEN, JR. and L. SOUTHWICK, JR., Quality in the MBA Program: Inputs, Outputs or Value Added?

M.T. DUGAN and K.A. SHRIVER, FASB Statement 33 Data Base: Compositional Characteristics, Potential Uses, and Sources of Measurement Error

R.D. MARCUS, Freshmen Retention Rates at U.S. Private Colleges: Results from Aggregate Data

D.C. DAHMANN, The Survey of Income and Program Participation as a Source of Migration Data

H. SAHAI, Subpopulation Comparisons of Aptitude Scores of the 1980 High School Seniors - An Analysis of the High School on Beyond Survey

L.S. ROSE and H.L. KINGMA, Seasonal Migration of Retired Persons: Estimating its Extent and its Implications for the State of Florida

E. DALGAARD, An Input-Output Analysis of Danish Trade and Specialization 1966-1983

J.G. HIRSCHBERG, Economic Experiment Data: A Primer on the use of time of Day Electricity Pricing Data

F.G. ADAMS, G. FAULHABER and S. SIWARAKSA, Measuring Services Output - The Wharton index of Services Production

R.I. LERMAN and D.L. LERMAN, Income Sources and Income Inequality: Measurements from three U.S. Income Surveys

D. BLAKE, The Investments and Returns of Private Sector Pension Funds in the UK 1963-1978

B. ORR and J. BUONGIORNO, Improving Estimates of Employment in Small Geographic Areas

T.I. GARNER, K.D. ZIESCHANG and R.D. MILLER, Using the Consumer Expenditure Survey Data: Past, Present, and Future Research

S.B. COHEN, A.E. JOHNSON and B.L. CARLSON, An Analysis of Part-Year Nonresponse in the Household Component of the National Medical Expenditure Survey

Contributors to Articles for Volume 15 